\title{
How the Inflation Affect the Commercial Bank Deposit Funds in Indonesia (2016 - 2018)?
}

\author{
Vindaniar Y. Putri*, Dwinta Firda Purnama \\ Department of Finance and Banking Administrative \\ Vocational Program, Universitas Indonesia \\ Depok, Indonesia \\ *vindaniar.putri@ui.ac.id, dwintafirdapurnama@gmail.com
}

\begin{abstract}
The purpose of writings this research was to determine the condition of investment growth of commercial bank deposit products in Indonesia from 2016 to 2018 and to find out the correlation between inflation growth and the growth of deposit on-call funds, time deposits, and certificates of deposit in commercial banks in Indonesia. Data for this writing obtained from the official websites of the Indonesian Deposit Insurance Corporation and Bank Indonesia. The variables used are inflation and growth data on commercial bank deposits from January 2016 to December 2018. To answer the problem formulation, the method used in this paper was a descriptivecorrelation analysis. The test was supported by SPSS 29 program. The outputs from the test showed there are correlations made between inflation growth with growth in deposits on-call, time deposits, and certificates of deposit in commercial banks during 2016-2018. However, the association that occurred was not significant. The insignificance of the correlation can be due to the fluctuations in the growth of deposit funds that have greater or lesser volatility when compared to fluctuations that occur in the growth of inflation.
\end{abstract}

Keywords—investment, correlation, inflation, deposit funds

\section{INTRODUCTION}

Deposits are one of the investment instruments that is commonly known among the public long before other investment instruments such as stocks and bonds are known today [1]. Deposits are defined as saving from third parties which the withdrawal can only be made within a certain period according to the agreement between the third party and the bank concerned [2]. On deposits, depositors may set their specific criteria of deposit such as a minimum amount of money as well as the time of deposit [3]. Deposits consist of various types such as time deposits, certificates of deposit, and call deposits.

In practice, public desire to save funds in the deposits form is driven by the interest rates offered. The more favourable deposit interest rate, the more it attracts the public to invest in deposits. The variables such as economic liquidity development, inflation rate, economic development, CAR (Capital Adequacy Ratio), ROA (Return on Asset), Bank
Indonesia interest rate, and LDR (Loan to Deposits Ratio) are determinant factors of the deposit interest rates [4].

According to Indonesian Banking Statistics data, as much as $77 \%$ of public funds are placed in deposits and saving in 2017. This data shows that deposit products still dominate the direction of investment in Indonesian society. Thus, depositors need to pay attention to the factors that affect deposit rates.

In 2016-2018, the overall deposit rate at commercial banks was above inflation. Inflation at that time was under pressure due to the normalization carried out by the United States on the Fed. The inflation rate is also maintained at $3 \%-4 \%$ with a standard deviation of $1 \%$. Also, 2018 was a turning point in the trend of deposit interest rates, which initially continued to fall, turned upward.

Since 19 August 2016, the interest rate in Indonesia (BI Rate) has effectively changed to Bank Indonesia 7 Day Reverse Repo Rate or known as BI7DDR. The new interest rate or policy rate is implemented to strengthen the country's monetary framework. Since then, the BI7DDR instrument is used as the new policy rate because it can quickly affect the money market, banking and real sectors. It has led to changes not only in the market but also in the policy of guarantee interest rates.

The guarantee interest rate is the interest rate issued by the Indonesia Deposit Insurance Corporation (IDIC). The aim to issue the guarantee interest rate is to protect customer funds in a bank, also to manage the national monetary balance. The interest rate is determined based on the Bank Indonesia interest rate and the average national deposit interest rate. The guarantee interest rate acts as a safety belt so that a bank can still obtain third party funds without jeopardizing its liquidity.

The research namely "Factors Affecting Time Deposit Interest Rates at Commercial Banks in Indonesia“ [4] using multiple linear regression found that bank deposit rates affected by CAR (Capital Adequacy Ratio), ROA (Return on Assets), and LDR (Loan to Deposits Ratio), liquidity, and inflation rates. Meanwhile, another research found that inflation affects the movement of interest rates in Indonesia, but there is not vice versa. This is because Central Bank has imposed the BI 7- 
Day Repo Rate as the reference as the substitute of the BI rate $[5,6]$. The inflation has a lot to do with the amount of money. If inflation is high, then the government suppresses the money supply or regulates the liquidity of the economy. The effect of this policy is that private and state banks are competing to raise interest rates. The interest given by banks to the public is the main attraction for the public to deposit their money in the bank, while for banks, the more public funds that can be collected, will increase the bank's ability to finance its operational assets.

Other research also finds that interest rate has significant positive impact on banks deposits in both in long run and short run [7]. Moreover, interest rate has insignificant effect on commercial bank's deposits [8]. Interest rate has insignificant effect on saving in Islamic countries while significant positive impact on saving in non-Islamic countries. But no one considered long run and short run impact of interest rate on saving or bank deposits this study covers this aspect [7].

Therefore, in this study, we would like to describe the relationship between the inflation rate and the deposits fund movement in commercial banks that occurred in Indonesia (2016-2018).

\section{Methodology}

The observation period in this study was from January 2016 to December 2018. The quantitative data [9] source of this study was based on the IDIC research results. There are Commercial Bank Deposit Distribution data, inflation data, and the IDIC interest rate.

The independent variable in this study is the inflation growth $(\mathrm{X})(\Delta \mathrm{INF})$. Meanwhile, the dependent variable $(\mathrm{Y})$ in resolving this topic is the rate of return of call deposits $(\triangle \mathrm{DOC})$, time deposits $(\triangle \mathrm{TRD})$, and commercial bank deposit certificates $(\triangle \mathrm{COD})$. The dependent variables are defined as [10]:

- Call Deposit, deposit with a minimum time of seven days and a maximum of 30 days. Call Deposits are issued in the name of ownership and are usually in large amounts.

- Time deposit, type of deposits issued with a disbursement system using a specific period. This period varies from one to 24 months. Time deposits are issued under the name of an individual or an institution.

- Certificates of deposit, this type have a disbursement period of two until 12 months. Certificates of deposit are issued with a bearer system wherein the certificate of a deposit does not include the name of a specific individual or legal entity.

The formula of the rate of return in this study as follows [11]:

$$
\Delta Y=\frac{Y_{t}-Y_{t-1}}{Y_{t-1}}
$$

Where:

$\Delta \mathrm{Y}=$ rate of return for variable $\mathrm{Y}$.

$\mathrm{Y}_{\mathrm{t}} \quad=$ amount of funds per variable $\mathrm{Y}$ in period $\mathrm{t}$

$\mathrm{Y}_{\mathrm{t}-1}=$ amount of funds per variable $\mathrm{Y}$ in period $\mathrm{t}-1$.

The method of this study is a descriptive analysis. Then we use the correlation test to exam the hypotheses. We employ the descriptive method in line with its function, which to describe existing phenomena that take place at this time or in the past [12]. Meanwhile, the correlation analysis aims to analyse the relationship between two or more variables. Thus, how far the variations in a variable are related to one another [9]

However, before the correlation test, the data will undergo a normality test first. The purpose of a normality test is to analyse whether the residual value is normally distributed or not. Normal distribution data will reduce the possibility of bias. Kolmogorov-Smirnov Test is adopted to determine the normal distribution of data through the SPSS 29 for windows program. Suppose the significant value (Asymp. Sig) in the variable is greater than $5 \%(>0.050)$. In that case, the variable is normally distributed, whereas if the significant value (Asymp. Sig.) is smaller than the level of significant 5\% $(\alpha<0.050)$, then the variable is not normally distributed [13].

The correlation test used in this study is the Pearson Correlation test. Pearson correlation is one of the techniques developed by Karl Pearson to calculate the correlation coefficient. The purpose of this test is to find the relationship between the independent variable $(\mathrm{X})$ and the dependent variable (Y) [14]. The formula as follows:

$$
r_{x y}=\frac{n \sum_{i=1}^{n} x_{i} y_{i}-\sum_{i=1}^{n} x_{i} \sum_{i=1}^{n} y_{i}}{\sqrt{n \sum_{i=1}^{n} x_{i}^{2}-\left(\sum_{i=1}^{n} x_{i}\right)^{2}} \sqrt{n \sum_{i=1}^{n} y_{i}^{2}-\left(\sum_{i=1}^{n} y_{i}\right)^{2}}}
$$

$$
\begin{aligned}
& \text { Description: } \\
& \begin{array}{l}
\mathrm{r}_{\mathrm{xy}} \quad=\text { The correlation coefficient of } \mathrm{r} \\
\mathrm{x} \quad=\text { The value in the distribution of the variable } \mathrm{x} \\
\mathrm{y} \quad=\text { The value in the distribution of the variable } \mathrm{y}
\end{array}
\end{aligned}
$$

Pearson correlation is denoted by $\mathrm{r}$, provided that the value of $r$ cannot be more than the price $(-1 \leq r \leq 1)$. If $r=1$ means perfect negative correlation, $r=0$ means there is no correlation, and $\mathrm{r}=1$ means positive perfect correlation [15]. If the resulting significant value $<0.050$, the correlation that occurs is significant and if the significant value $>0.050$, the correlation that occurs is not significant. 
TABLE I. R VALUE INTERPRETATION

\begin{tabular}{|l|l|}
\hline Coefficient Interval & Correlation Level \\
\hline $0,00-0,199$ & Very weak \\
$0,20-0,339$ & Weak \\
$0,40-0,559$ & Moderate \\
$0,60-0,779$ & Strong \\
$0,80-0,999$ & Very strong \\
1 & Perfect \\
\hline
\end{tabular}

Based on the explanation in the table 1 above, the hypotheses of this study are:

\section{Hypothesis 1}

$\mathrm{Ha}_{1}$ : Inflation growth has a significantly positive correlation with the Call deposit funds rate of return for commercial banks.

\section{Hypothesis 2}

$\mathrm{Ha}_{2}$ : Inflation growth has a significantly positive correlation with time deposit funds rate of return for commercial banks.

\section{Hypothesis 3}

$\mathrm{Ha}_{3}$ : Inflation growth has a significantly positive correlation with certificate of deposit funds rate of return for commercial banks.

\section{RESULTS AND DISCUSSION}

\section{A. Descriptive Statistic}

TABLE II. DESCRIPTIVE STATISTIC

\begin{tabular}{|l|l|l|l|l|}
\hline \multicolumn{1}{|c|}{ Description } & \multicolumn{1}{|c|}{$\Delta$ DOC } & \multicolumn{1}{|c|}{$\Delta$ TRD } & \multicolumn{1}{|c|}{$\Delta$ COD } & \multicolumn{1}{c|}{$\Delta$ INF } \\
\hline Mean & 0.0124 & 0.0059 & 0.0302 & 0.0061 \\
\hline Median & 0.0178 & 0.0052 & -0.0070 & 0.0046 \\
\hline $\begin{array}{l}\text { Standard } \\
\text { Deviation }\end{array}$ & 0.1548 & 0.0118 & 0.2090 & 0.1051 \\
\hline Sample Variance & 0.0239 & 0.0001 & 0.0437 & 0.0110 \\
\hline Range & 0.7271 & 0.0502 & 1.2711 & 0.5619 \\
\hline Minimum & -0.3607 & -0.0228 & -0.2674 & -0.1910 \\
\hline Maximum & 0.3664 & 0.0274 & 1.0036 & 0.3709 \\
\hline Count & 36 & 36 & 36 & 36 \\
\hline
\end{tabular}

Based on table 2, the amount of data observed was 36 samples with an average value on the $\triangle \mathrm{DOC}$ variable was 0.0124 . The standard deviation of 0.1548 , which means that the maximum increase in the average value of $\triangle \mathrm{DOC}$ is +0.1548 . For $\triangle T R D$, an average value of 0.0059 and mean value of 0.0020 is obtained. The standard deviation is 0.0118 , which means the maximum increase in the average time deposit growth rate is +0.0118 , and the maximum decrease in the average time deposit growth rate is -0.0118 . For $\triangle C O D$, an average value of 0.0302 and a standard deviation of 0.2090 is obtained, which means that the value of the maximum increase in the average growth of certificates of deposit is +0.2090 and the maximum decrease in the average growth of certificates of deposit is -0.2090 . The inflation variable has an average value of 0.0061 and a standard deviation of 0.1051 .

\section{B. Normality Test}

TABLE III. NORMALITY TEST RESUlT

\begin{tabular}{|l|l|}
\hline \multicolumn{1}{|c|}{ Variable } & Asymp. Sig. (2-tailed) \\
\hline$\Delta \mathrm{DOC}$ & 0,200 \\
\hline$\Delta \mathrm{TRD}$ & 0.200 \\
\hline$\Delta \mathrm{COD}$ & 0.200 \\
\hline
\end{tabular}

Based on table 3, the results of the normality test using the Kolmogorov-Smirnov Test stated that significant level by $20 \%$. These results show that significant level is greater than $5 \%$. These results can be interpreted that the data is normally distributed in call deposit, time deposits, and certificates of deposit variables.

\section{Correlation Analysis}

This analysis is used to determine how much the correlation coefficient of variables $\mathrm{X}$ and $\mathrm{Y}$. also, to exam the level of correlation between variable $\mathrm{X}$ and variable $\mathrm{Y}$. Correlation test in this study uses Pearson correlation.

TABLE IV. CORRELATION COEFFICIENT

\begin{tabular}{|l|l|l|}
\hline No & Correlation & Coefficient \\
\hline 1 & $\Delta \mathrm{INF}-\Delta \mathrm{DOC}$ & 0.121 \\
\hline 2 & $\Delta \mathrm{INF}-\Delta \mathrm{TRD}$ & 0.238 \\
\hline 3 & $\Delta \mathrm{INF}-\Delta \mathrm{COD}$ & 0.073 \\
\hline
\end{tabular}

Table 4 shows the results of the correlation test between inflation (Variable X) and each type of deposits (call deposits, time deposits, and certificate of deposits) (Variable Y). Based on the table, the correlation coefficient between variables $\mathrm{X}$ and $\mathrm{Y}$ is all positive. It can be concluded that the correlation is linear. It means that if the growth of inflation (variable $\mathrm{X}$ ) increases by $1 \%$, there will be an increase in variable $\mathrm{Y}$ in the amount of the correlation coefficient value.

The Pearson correlation test between inflation and call deposit is 0.1211 . The result indicates that the variable has a very weak correlation with the level of the relationship (below $0.5)$. Meanwhile, the correlation between inflation and time deposits is 0.238 , which implies that the variable has a weak correlation level. Furthermore, the results of the correlation test between inflation and certificates of deposit also produced a weak correlation value $(0.073)$.

\section{Hypothesis Test}

TABLE V. SigNIFICANT LEVEL For EACH HyPOTHESIS TEST

\begin{tabular}{|l|l|}
\hline Hypothesis & Significant Value \\
\hline $\mathrm{Ha}_{1}$ & 0.481 \\
\hline $\mathrm{Ha}_{2}$ & 0.161 \\
\hline $\mathrm{Ha}_{3}$ & 0.671 \\
\hline
\end{tabular}


Based on table 5, significance value $\mathrm{Ha}_{1}$ shows 0.481 , which means a significant value> 0.050 . So that the correlation that occurs is not significant, then $\mathrm{Ha}_{1}$ is not accepted. Furthermore, the significance value of $\mathrm{Ha}_{2}$ is 0.161 , which means a significant value is higher than alpha (0.050). So, the correlation that occurs is not significant. The third hypothesis test shows a significance value of 0.671 (significant value> 0.050), and it can be suggested that that $\mathrm{Ha}_{3}$ was not accepted.

According to the test results above, it can be concluded that inflation has a correlation with the call deposits, time deposits, and certificates of deposit in commercial banks during the 2016-2018 period. Nevertheless, the correlation is not significant (significance value> 0.050). All the hypotheses test indicate that the level of the correlations is at a weak and very weak level. Moreover, the results of this study are in line with research conducted by Almilia and Utomo [4], Anwar and Ansari [5].

\section{E. Discussion}

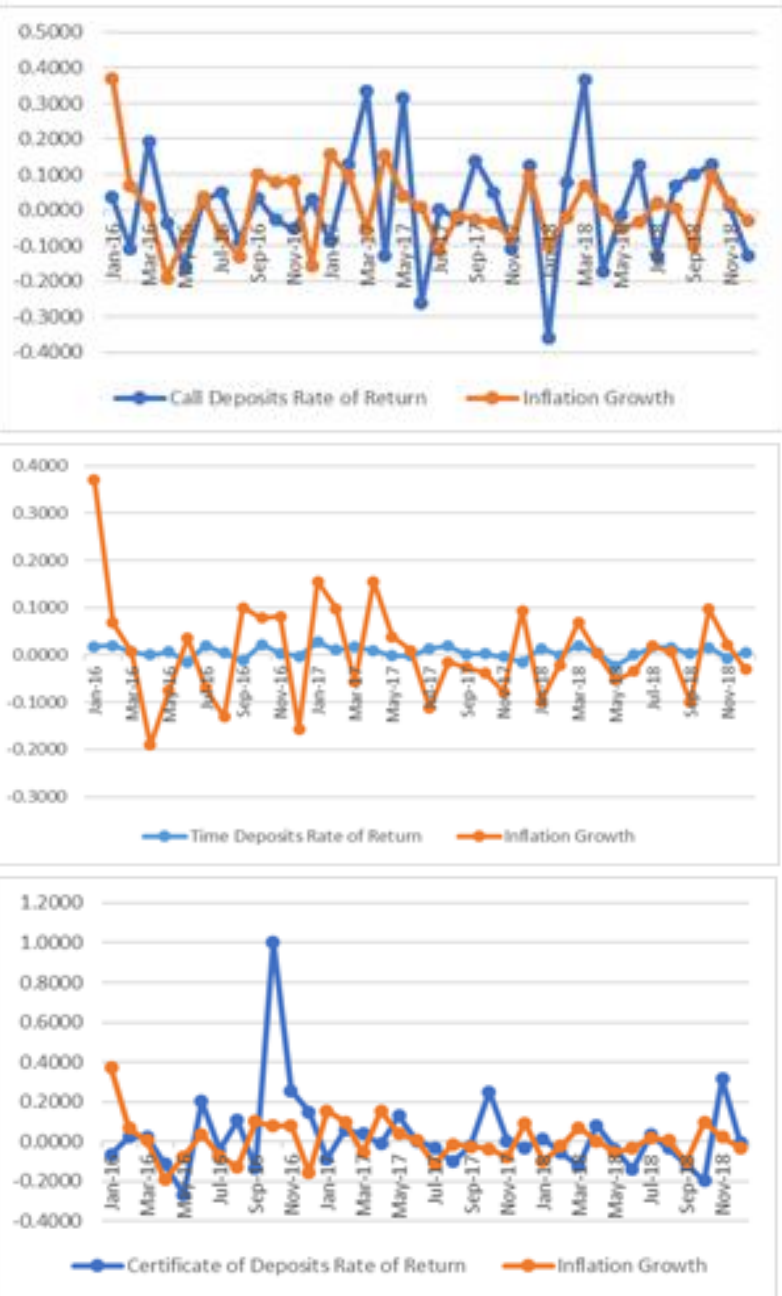

Fig. 1. Inflation growth compared to each deposit.
The hypothesis result states that Ha1 is not accepted. It can occur due to the high turnover of call deposit funds. Call deposit is the most liquid time deposit product among other types of deposits because the tenor of this deposit is only 7 to 30 days (1 month). Furthermore, the required initial deposit from the call deposit is also large, which is a minimum of $\mathrm{Rp}$. $100,000,000$ and a maximum of Rp. 2,000,000,000. Therefore, the tenor and the number of funds raised from one account can cause the fluctuation of funds in and out with great volatility.

Among the other two dependent variables, the rate of return in time deposits has the highest level of correlation, although it is not significant. It is because the fluctuations that occur in time deposit rate of return have lower volatility compared to other deposit products. Many people have time deposits so that their growth can be more stable. Besides, the fund movement in deposits instrument is likely because of deposit interest rate [15].

All of three dependent variables, the certificate of deposit rate of return has the weakest correlation. It may occur due to the highest volatility in the certificates of deposit rate of return. Certificates of deposit are the least common products owned by the public. It can cause a fluctuation in funds which will have a significant effect on the movement in a certificate of deposit funds. Furthermore, the funds collected from certificates of deposit per depositor are much higher than other types of deposits.

\section{CONCLUSION}

Based on the discussions above, the correlation test between inflation and call deposits, time deposits and certificates of deposit at commercial banks during 2016-2018 is weak and linear. The statistical results indicate that the correlations are not significant. One of the causes is the fluctuation in the growth of time deposit funds, which has greater or lesser volatility than the fluctuations in inflation.

\section{ACKNOWLEDGMENT}

Authors would like to send gratitude to the Indonesian Deposit Insurance Corporation (IDIC) for their support in completing this research paper. Especially to the Director of the Insurance Premium Handling Group and the Head of the IDIC Premium Calculation and Verification Division. Thank for the brainstorming, suggestions, and the special discussion sessions so that this paper can be well completed.

\section{REFERENCES}

[1] A. Halim, Analisis Investasi. Jakarta: Salemba Empat, 2005.

[2] Undang-undang Republik Indonesia No. 10 Tahun 1998, Perubahan Atas Undang-undang No.7 Tahun 1992 Tentang Perbankan, Jakarta: Republik Indonesia, 1998.

[3] J.A. Bikker and D.F. Gerritsen, "Determinants of Interest Rates on Time Deposits And Saving Accounts: Macro Factors, Bank Risk, and Account Features," International Review of Finance, vol. 18, no. 2, pp. 169-216, 2017 
[4] L.S. Almilia and A.W. Utomo, "Faktor-faktor yang Mempengaruhi Tingkat Suku Bunga Deposito Berjangka Pada Bank Umum di Indonesia," Jurnal Ekonomi dan Bisnis ANTISIPASI, vol. 10, no. Oktober, pp. 1-27, 2006.

[5] K. Anwar and Ansari, "Analisis Hubungan Kausalitas Antara Jumlah Uang Beredar, BI Rate, dan Inflasi di Indonesia Tahun 2010-2016," Jurnal Ekonomi Regional Unimal, vol. 1, no. Desember, pp. 79-88, 2018.

[6] L. Setiowati, Analisis Hubungan Kausalitas Antara Bi Rate Dengan Inflasi Di Indonesia Periode Juli 2006-Juli 2013 Menggunakan Metode Granger Dan Final Prediction Error. Surakarta: Universitas Muhammadiyah Surakarta, 2014.

[7] S. Mushtaq and D.A. Siddiqui, "Effect of Interest Rate on Bank Deposits: Evidences From Islamic And Non-Islamic Economies," Future Business Journal, vol. 3, no. 1, pp. 1-8, 2017.

[8] O.M. Hassan, "Effect of Interest Rates on Commercial Bank Deposits in Nigeria (2000-2013)," in Proceeding of The First American Academic
Research Conference on Global Business, Economics, Finance, and Social Sciences, New York, 2016.

[9] N. Sudjana and Ibrahim, Penelitian dan Penilaian Pendidikan. Bandung: Sinar Baru Algesindo, 2004.

[10] Kasmir, Dasar-dasar Perbankan. Jakarta: PT. Raja Grafindo Persada, 2012.

[11] Z. Bodie, A. Kane, and A.J. Marcus, Investment. New York: McGrawHill/Irwin, 2011.

[12] A. Furchan, Pengantar Penelitian dalam Pendidikan. Yogyakarta: Pustaka Pelajar Offset, 2004.

[13] I. Ghozali, Aplikasi Analisis Multivariate dengan Program IBM SPSS 19. Semarang: Badan Penerbit Universitas Diponegoro, 2011.

[14] S. Hadi, Statistik. Yogyakarta: Andi, 2004.

[15] I.A.P. Megawati and K.W. Kesuma, "Pengaruh PDRB, Inflasi, dan Dana Pihak Ketiga Terhadap Pertumbuhan Kredit PT. BPD Bali," E-Jurnal Manajemen Universitas Udayana, vol. 3, no. 2, 2014. 